\title{
APLIKASI BFT-HETEROTROPIK SISTEM DALAM PRODUKSI BENIH IKAN BANDENG (Chanos chanos)
}

\author{
Gusti Ngurah Permana, Haryanti, Ida Komang Wardana, dan Ahmad Muzaki \\ Balai Besar Penelitian dan Pengembangan Budidaya Laut \\ Jl. Br. Gondol Kec. Gerokgak Kab. Buleleng, Kotak Pos 140, Singaraja, Bali 81101 \\ E-mail: gustipermana@gmail.com
}

(Naskah diterima: 2 April 2014; Revisi final: 22 September 2014;

Disetujui publikasi: 10 November 2014)

\begin{abstract}
ABSTRAK
Salah satu kendala utama dalam pembenihan ikan bandeng adalah menurunnya kualitas benih dan ketersediaan rotifer. Teknologi bioflok yang melibatkan bakteri, mikroalga, dan bahan organik dalam air merupakan salah satu alternatif untuk memecahkan masalah tersebut. Tujuan penelitian ini adalah untuk mengevaluasi pengaruh Bio-Floc Technology (BFT) pada produksi benih ikan bandeng. Penelitian ini menggunakan bak beton volume $4 \mathrm{~m}^{3}$. Aplikasi bakteri heterotrop sebagai penyusun flok menggunakan tiga variasi perlakuan, yaitu: (A) bioflok + rotifer 100\% (100 ind./mL), (B) bioflok dan pengurangan rotifer $25 \%$ ( 75 ind./ $/ \mathrm{mL}$ ), (C) bioflok dan pengurangan $50 \%$ rotifer (50 ind./mL), dan sebagai kontrol (K) adalah tanpa pemberian bioflok atau pemeliharaan larva dengan $100 \%$ rotifer (100 ind./mL). Perlakuan tersebut diulang sebanyak tiga kali, data dianalisis menggunakan ANOVA. Hasil yang diperoleh menunjukkan bahwa bioflok merupakan kombinasi/campuran dari bakteri, mikroalga, detritus, dan protozoa. Bakteri pembentuk bioflok banyak didominasi oleh Bacillus. Hasil pengamatan terhadap sintasan ikan bandeng menunjukkan bahwa perlakuan bioflok + rotifer $100 \%$ memberikan sintasan tertinggi yaitu $26 \%$ berbeda nyata $(P<0,05)$, pengurangan rotifer $25 \%$ dengan sintasan $25 \%$, sedangkan pada pengurangan $50 \%$ feeding rate dengan sintasan $20 \%$ dan kontrol (tanpa bioflok) 15,03\%. Hal yang sama terjadi pada pertumbuhan benih bandeng yang menunjukkan bahwa pembentukan bioflok memberikan pertumbuhan yang lebih baik. Kualitas benih tertinggi yang ditunjukkan dari analisis rasio RNA : DNA diperoleh pada perlakuan bioflok + rotifer $100 \%(1,33)$; pengurangan rotifer $25 \%(1,08)$; pengurangan rotifer $50 \%(0,91) \%$ dan nilai yang paling rendah adalah kontrol $(0,42)$. Kualitas air media pemeliharaan relatif stabil terutama $\mathrm{pH}$ dan DO, sedangkan amonia antar perlakuan tidak berbeda nyata $(P>0,05)$. Populasi Vibrio dapat ditekan hingga mencapai $10^{2} \mathrm{cfu} / \mathrm{mL}$. Nampaknya, bioflok ini dapat menjadi makanan dengan nutrisi tinggi bagi ikan bandeng.
\end{abstract}

KATA KUNCI: bioflok, probiotik, ikan bandeng, RNA/DNA, rotifer

ABSTRACT: Aplication of bioflocs technology on milkfish hatchery. By: Gusti Ngurah Permana, Haryanti, Ida Komang Wardana, and Ahmad Muzaki

One of constrain in milkfish hatchery is reduction of fry quality and quality of rotifers as food. In order to overcome this constrain is biofloc technology. Its technology involved of floc forming bacteria, microalgae, and organic matter in the water. The study was aimed to evaluate the effect of BFT application to the growth of milkfish fry. Study of floc forming were tested by using concrete tank with capacity of $4 \mathrm{~m}^{3}$, and different feeding regimes were applied, (A) biofloc with standard feeding $100 \mathrm{ind} . / \mathrm{mL}$ (B) biofloc with reduction of feeding rate $25 \%$ (75 ind./ $\mathrm{mL}$ ), (C) biofloc with reduction of 
feeding rate $50 \%$ (50 ind./mL), (D) without added bacteria as control. Each treatment was triplicates, data was analyzed with ANOVA. The result showed that biofloc was formed from bacteria, microalgae, protozoa, and detritus. Bacteria floc was dominated by Bacillus spp. Survival rate of milkfish fry in treatment biofloc $+100 \%$ rotifer gave the highest value of $26 \%$, biofloc $+25 \%$ reduction of rotifer with a survival rate of $25 \%$, while biofloc $+25 \%$ reduction of rotifer with a survival rate of $20 \%$ and control (without biofloc) $15.03 \%$. Simillar result have shown that biofloc also gave a better growth. The highest value of RNA/DNA ratio in biofloc $+100 \%$ rotifer (1:33), biofloc + reduction $25 \%$ rotifer (1:08), while the reduction in of 50\% rotifer (0.91)\% and control (0.42) respectively. Water quality was shown stable during experiment, especially on $\mathrm{pH}$ and dissolved oxygen (DO), while ammonia was not significantly different between others. Vibrio populations can be reduced up to $10^{2} \mathrm{cfu} / \mathrm{mL}$. Apparently, bacteria will form a constituent biofloc that can be high protein live food for fish.

\section{KEYWORDS: biofloc, probiotic, milkfish, RNA/DNA, rotifer}

\section{PENDAHULUAN}

Teknologi pembenihan ikan bandeng (Chanos chanos) yang dikembangkan oleh Balai Besar Penelitian dan Pengembangan Budidaya Laut, Gondol telah diadopsi melalui teknologi hatcheri skala rumah tangga (HSRT) dan telah menjadi usaha utama di Bali Utara. Walaupun sudah berkembang lama masih dijumpai kendala di antaranya penurunan kualitas benih yang salah satunya disebabkan oleh kualitas dan kuantitas sediaan pakan alami rotifer. Penggunaan Nannochloropsis dan rotifer sebagai pakan utama masih memiliki beberapa permasalahan seperti ketersediaan pakan yang tidak stabil yang menyebabkan pasok pakan berkurang yang berakibat kualitas larva cenderung menurun. Produksi ikan bandeng sangat dipengaruhi oleh kualitas telur, kualitas pakan dan manajemen pemeliharaan.

Teknologi bioflok sebagai teknologi alternatif untuk memecahkan permasalahan tersebut, yang melibatkan konsorsium bakteri pembentuk flok dan mikroorganisme lain di antaranya bakteri, mikroalga, dan protozoa. Sistem bioflok dalam budidaya ikan nila diketahui mampu meningkatkan produktivitas hingga 30 kali dengan pergantian air yang sedikit (Wilson, 2008). Bioflok terdiri atas 70\%$80 \%$ mikro dan makroorganisme, termasuk di dalamnya bakteri heterotrof, alga, fungi, cilliata, flagellata, rotifer, nematoda, metazoa, dan detritus (Briggs, 2007). Teknologi ini tidak hanya bergantung pada plankton tetapi juga sangat bergantung pada mikroba dan bahan organik dalam air sehingga kualitas air menjadi lebih stabil. Selain itu, mikroba mempunyai kemampuan untuk merubah limbah nitrogen yang berasal dari pakan yang tidak termakan, feses dan kumpulan mikroorga- nisme tersebut menjadi makanan berprotein tinggi bagi ikan bandeng. Menurut Briggs (2007), bioflok mengandung $25 \%-56 \%$ protein, $25 \%-29 \%$ bahan organik dan kandungan asam amino yang tinggi.

Aplikasi mikroba sebagai single cell protein, dapat berperan sebagai pakan ikan bandeng berprotein tinggi dan dapat menjaga kestabilan lingkungan pemeliharaan. Penggunaan teknologi bioflok diharapkan dapat meningkatkan produktivitas dan kualitas benih. Kondisi nutrisi pakan yang diberikan pada larva stadia awal terutama pakan alami merupakan hal penting yang mempunyai hubungan terhadap pertumbuhan dan sintasan larva. Salah satu metode yang sensitif untuk menggambarkan keabsahan rata-rata pertumbuhan sampel yang dianalisis adalah rasio RNA/DNA. Jumlah DNA yang konstan dalam spesies dibandingkan dengan jumlah RNA yang mengalami perubahan pada sintesis protein dan pertumbuhan dapat mengekspresikan kualitas larva (Segnini \& Chung 1997; Chicharo et al., 1998; Haryanti et al., 2006). Untuk itu, dalam upaya meningkatkan produksi benih bandeng, penelitian ini dilakukan dengan tujuan mengevaluasi pengaruh aplikasi bioflok pada produksi benih ikan bandeng dan mengidentifikasi susunan mikroorganisme yang tumbuh dalam bioflok tersebut dalam upaya meningkatkan kualitas dan kuantitas benih ikan bandeng.

\section{BAHAN DAN METODE}

Penelitian ini dilakukan dengan aplikasi bioflok yang dihasilkan dari bakteri komersial. Uji kualitas benih atau larva yang dihasilkan dilakukan dengan uji vitalitas (fisik dan kimia) dan nilai rasio RNA/DNA. Aplikasi 
teknologi bioflok menggunakan bakteri komersial A pembentuk flok yang didominansi oleh bakteri Bacillus. Penelitian ini menggunakan perlakuan yaitu pemberian: (A) bioflok + rotifer 100\% (100 ind./mL), (B) bioflok dan pengurangan rotifer $25 \%$ (75 ind./mL), (C) bioflok dan pengurangan $50 \%$ rotifer (50 ind./ $\mathrm{mL}$ ), dan sebagai kontrol (K) adalah tanpa pemberian bioflok atau pemeliharaan larva dengan $100 \%$ rotifer (100 ind./mL). Penelitian dilakukan pada bak beton volume $4 \mathrm{~m}^{3}$ dengan kondisi awal kultur menggunakan air laut bersalinitas 32-34 mg/L. Kepadatan telur yang ditebar 40 ekor/L. Rancangan percobaan menggunakan Rancangan Acak Lengkap (RAL) dengan masing-masing perlakuan diujikan dengan tiga ulangan.

Parameter yang diamati adalah sintasan larva dan kualitas larva. Pengujian kualitas larva secara fisik dilakukan melalui pengeringan dan secara kimia dengan perendaman dalam larutan formalin dengan konsentrasi berbeda. Pengujian dengan pengeringan dilakukan di atas kertas tissu selama tiga menit dan lima menit. Pengujian secara kimiawi dilakukan perendaman dengan formalin yang mempunyai konsentrasi berbeda, yaitu: 50, 100, 150, dan 200 mg/L selama 15 menit. Selanjutnya dilakukan analisis RNA/DNA pada benih. Tahap terakhir adalah analisis kandungan nutrisi, yaitu protein, lemak, dan karbohidrat.

\section{Prosedur Karakterisasi DNA Bakteri Pembentuk Flok}

\section{Isolasi Bakteri SUPER NB}

Menginokulasi bakteri probiotik komersial $0,1 \mathrm{mg} / \mathrm{L}$ untuk perlakuan dalam marine agar dengan pengenceran $10^{0}-10^{4}$. Setelah didapat kultur bakteri, dilakukan purifikasi koloni yang terbentuk dengan teknik usar 3 kuadran. Setelah diperoleh koloni tunggalnya bakteri dikultur ke dalam media cair (marine broth) dengan volume $2 \mathrm{~mL}$. Hasil kultur kemudian disentrifugasi dan diambil peletnya untuk dilakukan analisis DNA.

\section{Ekstraksi DNA}

Pelet plasmid DNA ditambahkan dengan $475 \mu \mathrm{L}$ buffer TE dan $25 \mu \mathrm{L}$ SDS kemudian divortex. Sebanyak $5 \mu \mathrm{L}$ Proteinase Kinase (PK) ditambahkan sebagai enzim pemecah protein. Inkubasi dilakukan pada suhu $37^{\circ} \mathrm{C}$ selama 60 menit, setelah inkubasi dalam eppendorf ditambahkan $90 \mu \mathrm{L} 5 \mathrm{M} \mathrm{NaCl}$ dan $75 \mu \mathrm{L} \mathrm{CTAB}$
(Cetyl Trimethyl Ammonium Bromide) inkubasi kedua dilakukan pada kondisi suhu $65^{\circ} \mathrm{C}$ selama 20 menit. Setelah itu, ditambahkan khloroform dan isoamil alkohol (24:1), dan disentrifugasi $13.500 \mathrm{rpm}$ selama lima menit. Supernatan yang dihasilkan diambil kemudian ditambahkan isopropanol $360 \mu \mathrm{L}$, selanjutnya disentrifugasi pada kecepatan 13.500 rpm selama lima menit. Pelet yang terbentuk diambil kemudian ditambahkan ethanol $70 \%$ sebanyak $1 \mathrm{~mL}$, kemudian disentrifugasi lagi dengan kecepatan 13.500 rpm selama enam menit. Pelet hasil sentrifugasi ditambahkan dengan buffer TE $100 \mu \mathrm{L}$.

\section{Pengukuran Konsentrasi DNA}

Setelah mengisolasi DNA bakteri, dilakukan pengukuran konsentrasi DNA sampel. Dari hasil isolasi DNA diambil $1 \mu \mathrm{L}$ dan diencerkan 70x kemudian dimasukkan ke dalam kuvet, lalu diukur dengan prinsip spektrofotometri dengan $\lambda 260 \mathrm{~nm}$ dan $280 \mathrm{~nm}$.

\section{Amplifikasi DNA (PCR)}

Amplifikasi dilakukan menggunakan larutan pereaksi dengan total volume $10 \mu \mathrm{L}$ yang terdiri atas: double distillited $\mathrm{H}_{2} \mathrm{O}: 4,1 \mu \mathrm{L} ; 10$ mM dNTP : 0,2 $\mu \mathrm{L} ; 25 \mathrm{mM} \mathrm{MgCl}_{2}$ : 1,5 $\mu \mathrm{L}$; buffer PCR $2 \mu \mathrm{L}$ primer (2AAM2 sekuen 5'-CTG CGA CCC AGA GCG G -3') : $25 \mu \mathrm{M}): 1 \mu \mathrm{L}$; Taq DNA polymerase : $0,2 \mu \mathrm{L}$; template DNA : $1 \mu \mathrm{L}$ (15$20 \mathrm{ng}$ ). Total PCR mix tiap sampel : $10 \mu \mathrm{L}$. Program thermal cycler untuk amplifikasi DNA terlihat pada Tabel 1.

\section{Elektroforesis}

Gel elektroforesis menggunakan agarose $2 \%$ dalam buffer SB 0,5x + Ethidium Bromide $(10 \mathrm{mg} / \mathrm{mL}$ ). Agarose yang telah dilarutkan dalam buffer SB dipanaskan menggunakan microwave. Setelah matang dituang dalam cetakan, dan didinginkan pada suhu ruang, lalu dimasukkan dalam chamber elektroforesis. Setelah gel siap sampel dimasukkan kemudian dielektroforesis dengan tegangan 100 volt.

\section{Prosedur Penelitian Analisis RNA/DNA}

Ekstraksi RNA dilakukan dengan menggunakan jaringan daging atau keseluruhan dari larva (100 mg) digerus dalam $150 \mu \mathrm{L}$ Trizol, kemudian ditambahkan sebanyak $850 \mu \mathrm{L}$ Trizol dan diinkubasi pada suhu $25^{\circ} \mathrm{C}$ selama lima menit, dan disentrifugasi dengan kecepatan $12.000 \mathrm{rpm}$ selama sepuluh menit pada 
Tabel 1. Program thermal cycler PCR DNA bakteri pembentuk flok

Table 1. Thermal cycler program for PCR DNA floc forming bacteria

\begin{tabular}{lccc}
\hline \multicolumn{1}{c}{$\begin{array}{c}\text { Langkah } \\
\text { Step }\end{array}$} & $\begin{array}{c}\text { Suhu } \\
\text { Tem perat ure }\left({ }^{\circ} \mathrm{C}\right)\end{array}$ & $\begin{array}{c}\text { Waktu (detik) } \\
\text { Time (second) }\end{array}$ & $\begin{array}{c}\text { Siklus } \\
\text { Cycles }\end{array}$ \\
\hline Denaturasi awal (Predenaturation) & 95 & 120 & \\
\hline Denaturasi (Denaturation) & 95 & 15 & 2 \\
Aneling (Annealing) & 45 & 15 & \\
Ekstensi (Extension) & 70 & 60 & 38 \\
\hline Denaturasi (Denaturation) & 94 & 5 & \\
Aneling (Annealing) & 45 & 5 & \\
Ekstensi (Extension) & 70 & 30 & \\
Ekstensi akhir(Post extension) & 70 & & \\
\hline
\end{tabular}

$4^{\circ} \mathrm{C}$. Supernatan yang dihasilkan dipindahkan pada eppendorf baru dan ditambahkan 200 $\mu \mathrm{L}$ khloroform. Inkubasi dilakukan pada suhu ruang selama sepuluh menit 20 detik dan disentrifugasi $12.000 \mathrm{rpm}$ selama sepuluh menit pada suhu $4^{\circ} \mathrm{C}$. Supernatan dipindahkan ke dalam epperdorf baru dan ditambah 670 $\mu \mathrm{L}$ isopropanol dan diinkubasi pada suhu ruang selama sepuluh menit, kemudian disentrifugasi $12.000 \mathrm{rpm}$ selama sepuluh menit $\left(4^{\circ} \mathrm{C}\right)$, pelet ditambah $500 \mu \mathrm{L}$ alkohol $70 \%$, dan diamkan 30 menit $\left(25^{\circ} \mathrm{C}\right)$ dan disentrifugasi $12.000 \mathrm{rpm}$ selama sepuluh menit pada suhu $4^{\circ} \mathrm{C}$. Pelet RNA dikeringkan ( \pm 20 menit) dilarutkan dengan $\mathrm{ddH}_{2} \mathrm{O}$.

Ekstraksi genom DNA mengikuti modifikasi metode Ovenden (2000). Keseluruhan dari larva digerus dalam $500 \mu \mathrm{L}$ larutan $10 \%$ Chelex-I00 dimasukkan ke dalam eppendorf tube dan ditambahkan $5 \mu \mathrm{L}$ proteinase kinase (20 $\mathrm{mg} / \mathrm{mL}$ ) kemudian diinkubasi pada suhu $55^{\circ} \mathrm{C}$ dalam waterbath selama 3-4 jam. Setelah itu, suhu dinaikkan menjadi $89^{\circ} \mathrm{C}$ dan diinkubasi selama delapan menit dan didinginkan pada suhu kamar hingga dingin sebelum ditambahkan $55 \mu \mathrm{L}$ buffer TE (Tris-EDTA) H 8,0. Genom DNA diperoleh dengan melakukan sentrifugasi selama lima menit dengan kecepatan 13.000 rpm. Larutan pada lapisan atas dan berwarna jernih merupakan genom DNA dipindahkan ke dalam eppendorf tube baru dan disimpan pada suhu $-20^{\circ} \mathrm{C}$. Untuk mendapatkan RNA dilakukan dengan menggerus 100 $\mathrm{mg}$ jaringan daging atau keseluruhan larva dalam $1.000 \mu \mathrm{L}$ Trizol dan diinkubasi selama lima menit kemudian dilakukan sentrifugasi selama sepuluh menit pada suhu $4^{\circ} \mathrm{C}$ dengan kecepatan $12.000 \mathrm{rpm}$. Lapisan atas/supernatan yang dihasilkan diambil dan ditambahkan $200 \mu \mathrm{L}$ khloroform dan divortex selama 20 detik selanjutnya diinkubasi pada suhu ruang selama sepuluh menit. Sentrifugasi selama sepuluh menit pada suhu $4^{\circ} \mathrm{C}$, supernatan yang diperoleh ditambahkan larutan isopropanol sebanyak $670 \mu \mathrm{L}$ dan untuk mendapatkan pelet RNA dilakukan dilakukan sentrifugasi selama sepuluh menit. Pelet yang dihasilkan dicuci dengan $500 \mu \mathrm{L}$ (70\% ethanol dingin) diamkan selama 30 menit. Sentrifugasi yang terakhir dilakukan untuk mengkonsentrasikan pelet RNA, diencerkan dengan $\mathrm{ddH}_{2} \mathrm{O}$ steril sebanyak $50 \mu \mathrm{L}$.

\section{Pengukuran dengan Gene Quant}

Pengukuran konsentrasi RNA dan DNA dilakukan dengan menggunakan mesin gene quant. Pengenceran RNA total dan genon DNA sebesar 70 kali untuk memudahkan penghitungan. Mesin gene quant dikalibrasi menggunakan blanko TE dengan menggunakan panjang gelombang masing-masing 260 dan $280 \mathrm{~nm}$. Dengan memasukkan larutan sampel ke dalam kuvet, maka dapat diketahui konsentrasi genom DNA dan RNA dari total setiap sampel.

Pengamatan biologi meliputi sintasan dan pertumbuhan bobot serta panjang ikan bandeng, populasi total bakteri dan Vibrio, serta kualitas air (amonia, nitrit, nitrat, suhu, pH, salinitas, DO) dan kadar $\mathrm{H}_{2} \mathrm{~S}$ tanah pada akhir riset. Analisis data secara deskripsi, grafik, dan tabulasi. 


\section{HASIL DAN BAHASAN}

\section{Identifikasi Komposisi Mikroorganisme Pembentuk Flok}

Hasil amplifikasi PCR dengan menggunakan primer 2AAM2 terlihat pada Gambar 1. Hasil amplikasi menunjukkan fragmentasi yang berbeda pada strain yang berbeda. Dengan membandingkan dengan strain yang ada maka performansi strain dapat ditentukan.

Dominasi Bacillus spp. sangat tinggi pada probiotik super NB terlihat dari Gambar 1A, karakterisasi dalam media agar keempat strain bakteri yang terindentifikasi terlihat pada Gambar 1B. Secara alami, bioflok dapat terbentuk dari mikroalga, bakteri, protozoa, dan mikroorganisme lain yang memanfaatkan senyawa anorganik hasil dekomposisi bahan organik seperti sisa pakan, feses. Bakteri yang mampu membentuk bioflok di antaranya: Zooglea ramigera, Escherichia intermedia, Paracolobacterium aerogenoids, Bacillus subtilis, Bacillus cereus, Flavobacterium, Pseudomonas alcaligenes, Sphaerotillus natans, Tetrad, dan Tricoda (Avnimelech, 2007).

Penampilan bioflok yang diambil dari media fermentasi tertera pada Gambar 2. Nampak bahwa flok yang terbentuk terdiri atas bermacam-macam mikroorganisme seperti: bakteri, mikroalga, protozoa, detritus, dan organisme lain. Pada hari ke-5 atau minggu pertama pemeliharaan, terlihat bahwa kumpulan biomassa mikroorganisme/bioflok masih sedikit. Bioflok hanya terdiri atas detritus dan beberapa mikroalga, sementara bakteri yang ditambahkan belum berkembang dalam air pemeliharaan ikan bandeng. Bioflok dapat tumbuh dengan cepat setelah minggu kedua pemeliharaan. Nampaknya, aplikasi ini berkorelasi positif terhadap pembentukan bioflok. Sedangkan pada kontrol, bioflok yang terjadi berupa kumpulan biomassa kecil dan didominasi oleh plankton (algae floc) terlihat pada Gambar 2B. Menurut Anonymous (2008), pembentukan dan pemeliharaan bioflok pada dasarnya mengubah senyawa organik dan anorganik yang mengandung senyawa karbon $(\mathrm{C})$, hidrogen $(\mathrm{H})$, oksigen $(\mathrm{O})$, dan nitrogen (N) dengan sedikit ketersediaan fosfor (P) menjadi massa sludge berupa bioflok dengan menggunakan bakteri pembentuk flok (flocs forming bacteria) yang menyintesis biopolimer polihidroksi alkanoat sebagai ikatan bioflok. Mikroorganisme penyusun bioflok dapat menjadi makanan berprotein tinggi bagi ikan bandeng. Selain itu, berlimpahnya unsur $\mathrm{N}$ yang tidak termanfaatkan pada kontrol menyebabkan lumut tumbuh subur sehingga mengganggu pergerakan larva dan kompetisi oksigen pada malam hari (Gambar 2D).

Indikator keberhasilan pembentukan bioflok adalah perubahan warna air menjadi kecoklatan dan seperti awan bergerak dalam

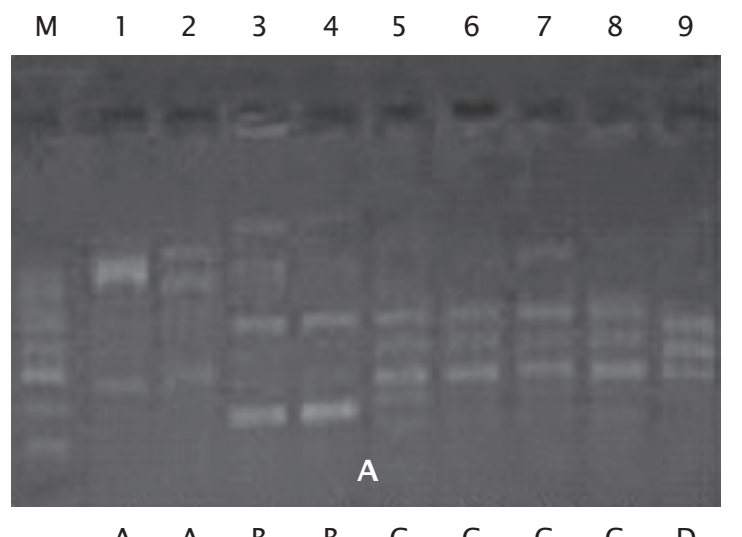

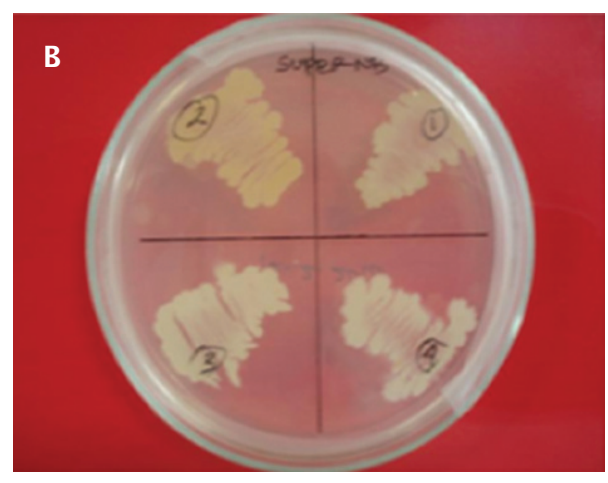

Karakterisasi pada media agar (Characterization on agar media)

Keterangan (Note):

M = Marker 100 bp DNA ladder; pita 1-2: Pseudomonas sp.; pita 3-4: Nitrobacter sp.; pita 5-8: Bacillus sp.; pita 9: Aerobacter sp. ( $M=100$ bp DNA ladder; band 1-2: Pseudomonas sp.; band 3-4: Nitrobacter sp.; band 5-8: Bacillus sp.; band 9: Aerobacter sp.)

Gambar 1. Genotipe strain bakteri pembentuk bioflok super NB

Figure 1. Genotype pattern of bacteria strain forming biofloc super NB 


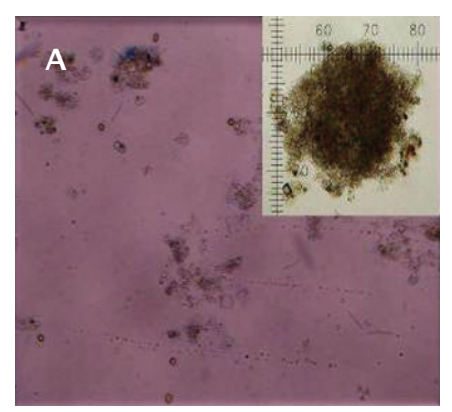

Flok campuran (bakteri, rotifer, detritus dan protozoa) (Floc mix (Bacteria, rotifer, detritus and protozoa))

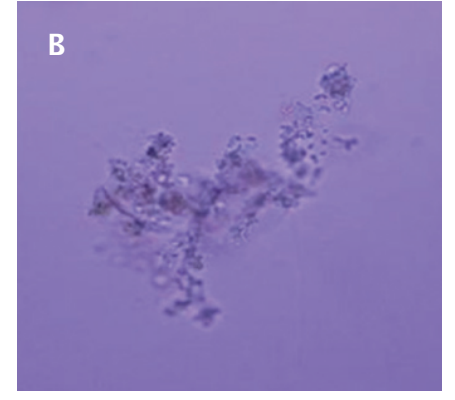

Flok chlorella (Floc chlorella)

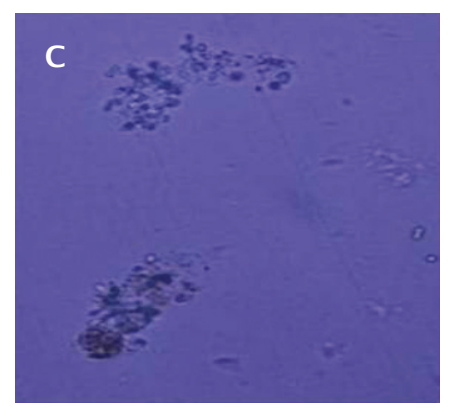

Flok bakteri dan chlorella (Floc bacteria and chlorella)

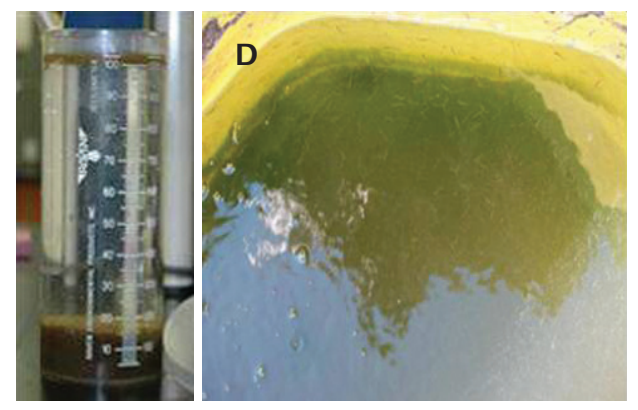

Sampel flok Lumut di pinggir bak (Fillamen-

Floc sample tous algae in tank)

Gambar 2. Performa bioflok yang dihasilkan dari pemeliharaan benih bandeng Chanos chanos (pembesaran 100x)

Figure 2. Biofloc performance resulted from milkfish Chanos chanos reared tank (100x magnification)

arus air di dalam bak. Tingkat $\mathrm{pH}$ air cenderung berada di sekitar 7 (antara 7,2-7,8) dengan sedikit perbedaan $\mathrm{pH}$ antara pagi dan siang hari $(0,02-0,2)$. Bahkan Bacillus sendiri, sebagai pengguna karbon dari bahan organik dan menghasilkan karbon dioksida $\left(\mathrm{CO}_{2}\right)$.

Menurut Avnimelech (2007), keberhasilan produksi bioflok bergantung pada: (1) ketersediaan substrat organik untuk komunitas mikroba, dari sumber eksternal (suplai pakan, aktivitas alga) atau rasio $\mathrm{C} / \mathrm{N}$ dan dari ekskresi feses ikan, (2) spesies dan ukuran ikan dan sifat memangsa, ukuran, dan kepadatan flok hubungannya dengan ketersediaan dan laju pemberian pakan buatan, sehingga pakan dimanfaatkan dan diakumulasikan oleh ikan mujair, sedangkan feses dimanfaatkan sebagai substrat untuk menghasilkan bioflok, (3) biodegradasi flok bergantung pada komunitas mikroba yang berasosiasi dengan bioflok (bak- teri, protozoa, dan mikroorganisme lain), (4) proses pembentukan bioflok dipengaruhi oleh lingkungan dan kondisi operasional (suhu, salinitas, laju pergantian air, dan intensitas cahaya).

\section{Komposisi Nutrisi Flok}

Kandungan protein dari flok yang terbentuk pada akhir pemeliharaan dengan pemberian bioflok + rotifer $100 \%$ sebanyak $(30,6 \%)$; bioflok dan pengurangan rotifer $25 \%(22,95 \%)$; bioflok dan pengurangan rotifer $50 \%$ (17,21\%); dan kontrol tanpa bioflok (7,9\%). Kandungan protein flok tertinggi dihasilkan dari perlakuan bioflok + rotifer $100 \%$. Namun demikian kandungan protein flok yang terdapat pada hatcheri ikan bandeng lebih rendah jika dibandingkan dengan kandungan protein flok pada tambak 32\%-68\% (Anonymous, 2008). Hal tersebut dapat disebabkan karena keterba- 
tasan ruang dan media pembentuk flok. Lebih lanjut dikemukakan bahwa kandungan protein flok pada pembesaran ikan nila di bak berkisar antara 30\%-50\% (Azim \& Little, 2008).

Bakteri tersebut diharapkan dapat merombak unsur nitrogen yang tersisa. Menurut Conguest \& Tacon (2006), komposisi flok terdiri atas protein kasar 35\%-50\% (arginin, lysine, dan methionine); lemak 0,6\%-12\% dan mineral $21 \%-32 \%$. Setiap gram $\mathrm{N}\left(\mathrm{NH}_{4}\right)$ memerlukan $3,57 \mathrm{~g} \mathrm{HCO}_{3} ; 15,17 \mathrm{~g} \mathrm{C}_{6} \mathrm{H}_{12} \mathrm{O}_{6}$ (karbohidrat); dan $4,71 \mathrm{~g} \mathrm{O}_{2}$ untuk menjadi $8,07 \mathrm{~g}$ bakteri; dan 9,65 $\mathrm{g} \mathrm{CO}_{2}$ (Ebeling et al., 2006).

Dalam proses pembentukan komunitas mikroba, prinsip dasarnya bahwa bakteri dan mikroorganisme lain memerlukan karbohidrat untuk pertumbuhannya. Sementara protein merupakan komponen yang besar untuk membentuk material sel baru, sedangkan nitrogen juga diperlukan sebagai elemen esensial. Jadi bakteri memerlukan metabolisme karbohidrat dan mengambil nitrogen anorganik terlarut (sebagian besar $\mathrm{NH}_{4}$ ) dan menghasilkan protein. Akumulasi bahan toksik nitrogen anorganik $\left(\mathrm{NH}_{4}\right.$ dan $\left.\mathrm{NO}_{2}\right)$ sebaiknya dicegah dalam sistem bioflok yaitu dengan menjaga rasio $\mathrm{C} / \mathrm{N}$ tinggi dan pengambilan ammonium dengan memanfaatkan komunitas mikroba (McIntosh, 2000).

\section{Sintasan Ikan Bandeng Chanos chanos}

Hasil pengamatan sintasan ikan bandeng terlihat pada Gambar 3 yang diberi perlakuan bioflok menunjukkan nilai yang lebih baik $(20,24 \%-26,60 \%)$ bila dibandingkan tanpa bioflok (15,03\%). Penggunaan bioflok selama pemeliharaan larva ikan bandeng memberikan kontribusi dalam menghasilkan sintasan yang baik jika dibandingkan dengan kontrol. Flok yang terbentuk sebagai biomassa mikroorganisme merupakan pakan alami yang mempunyai nilai nutrisi tinggi bagi ikan bandeng. Hal ini disinyalir mampu meningkatkan pertumbuhan dari benih bandeng.

\section{Pertumbuhan Ikan Bandeng}

Hasil pengamatan terhadap pertumbuhan panjang dan performa ikan bandeng (Gambar 4 dan 5) dengan interval waktu lima hari menunjukkan pertumbuhan yang berbeda nyata pada perlakuan A (bioflok + rotifer 100\%) dengan perlakuan lainnya dan kontrol. Hal ini dapat dipahami bahwa pertumbuhan tertinggi akan semakin meningkat dengan semakin tingginya ketersediaan pakan baik kualitas maupun kuantitasnya. Sementara, kontrol (tanpa bioflok) menunjukkan pertumbuhan yang relatif lambat.

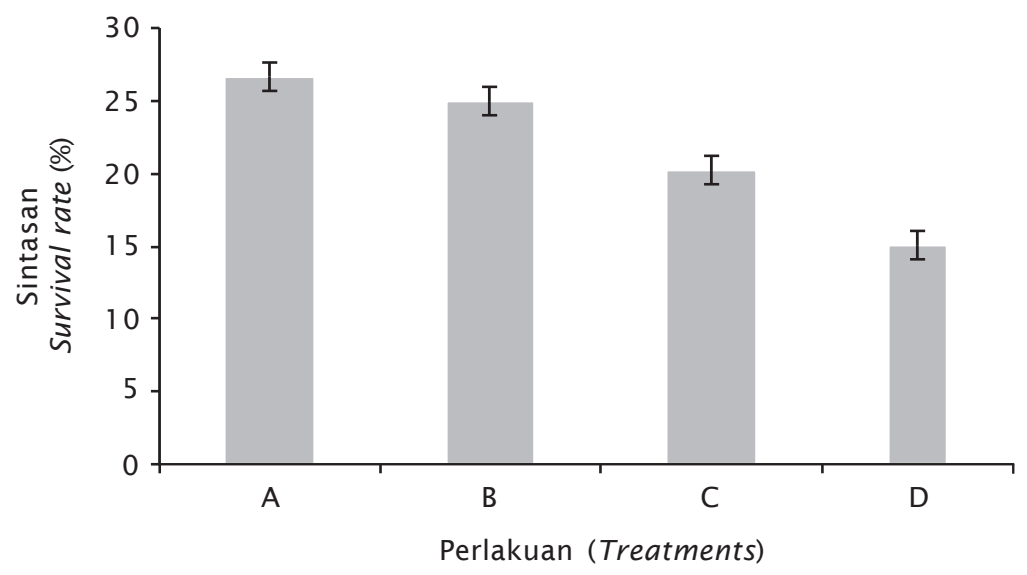

Gambar 3. Sintasan ikan bandeng setelah pemeliharaan dengan bakteri pembentuk bioflok yang berbeda, (A) bioflok + rotifer 100\%, (B) bioflok + pengurangan rotifer $25 \%$, (C) bioflok + pengurangan rotifer $50 \%$, (D) kontrol tanpa bioflok

Figure 3. Survival rate (\%) of milkfish after reared in different probitic forming biofloc, (A) biofloc + rotifer 100\%, (B) biofloc + reduction $25 \%$ rotifer, (C) biofloc + reduction $50 \%$ rotifer, (D) control without biofloc 


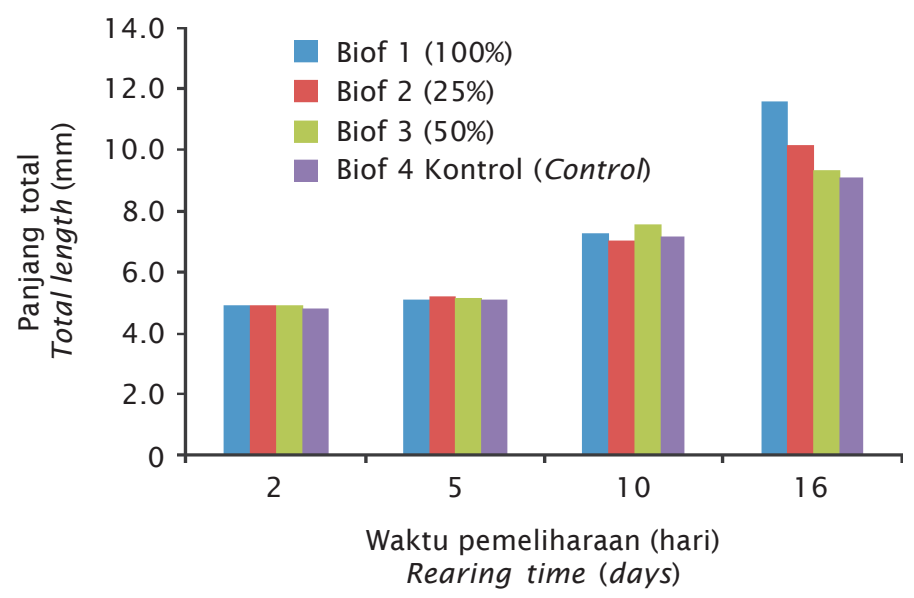

Gambar 4. Pola pertumbuhan panjang ikan bandeng dengan pemberian bakteri pembentuk bioflok yang berbeda

Figure 4. Growth pattern of length on milkfish reared with different probiotic forming bioflocs
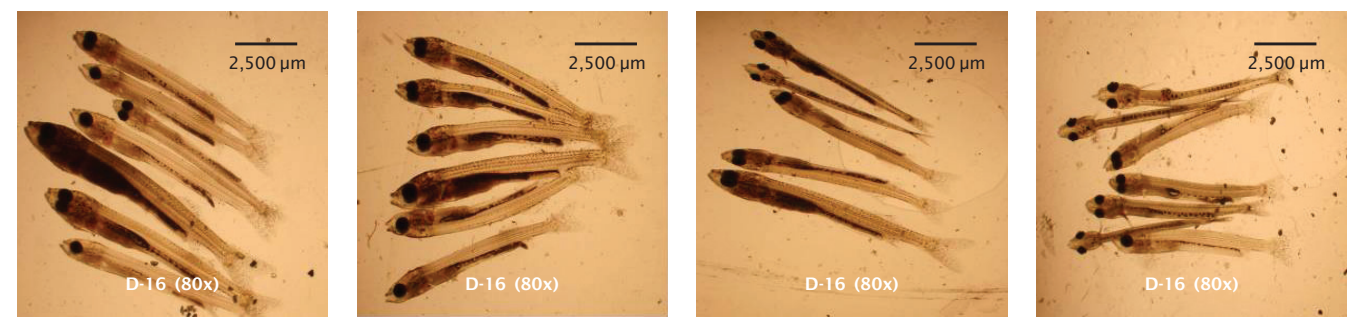

Gambar 5. Performa benih ikan bandeng dengan aplikasi bioflok dan tanpa bioflok (pembesaran 80x)

Figure 5. Performans of milkfish fry with and without biofloc application (80x magnification)

Dilihat dari gambaran histologi usus secara longitudinal, benih ikan bandeng yang diberi perlakuan aplikasi bioflok dan tanpa bioflok terlihat ada perbedaan yang jelas (Gambar 6). Pada perlakuan bioflok + rotifer $100 \%$ usus terlihat penuh terisi makanan yaitu rotifer dan organisme lain yang diduga adalah kumpulan flok, hal tersebut jauh berbeda dengan kontrol.

\section{Nilai Rasio RNA/DNA Benih Ikan Bandeng}

Hasil analisis RNA/DNA benih pada perlakuan pemberian bioflok + rotifer $100 \%$ adalah 1,33; bioflok + pengurangan rotifer $25 \%$ adalah 1,08; bioflok + pengurangan rotifer $50 \%$ adalah 0,91 ; dan kontrol tanpa pemberian bioflok adalah 0,42 (Gambar 7). Perbedaan nilai ini diduga berhubungan dengan adanya endogenous rhythm dalam produksi RNA, sehingga akan terjadi perubahan konsentrasi RNA. Selain itu, adanya kemungkinan kandungan RNA dan DNA dari flok yang ikut dianalisis, karena sampel yang dipergunakan adalah total larva. Rasio RNA/DNA yang tinggi juga berhubungan dengan nilai nutrisi pakan dan kondisi pemeliharaan yang baik, sehingga rasio tersebut dapat digunakan sebagai indikator kondisi fisiologis dalam sistem pemeliharaan ikan (Chicharo et al., 1998; Segnini \& Chung, 1997).

Nilai rasio RNA/DNA yang semakin tinggi $(>1)$ mengindikasikan bahwa benih tumbuh dengan laju dan kualitas yang lebih baik (Buckley, 1984; Caldarone \& Buckley, 1997; Jung \& Clemmesen, 1997; Chicharo et al., 1998: Segnini \& Chung, 1997). Menurut Kono et al. (2003), rasio RNA/DNA dapat digunakan 


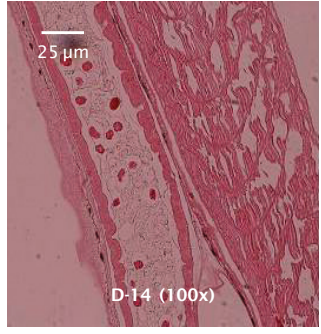

Bioflok + rotifer $100 \%$ Biofloc + rotifer 100\%

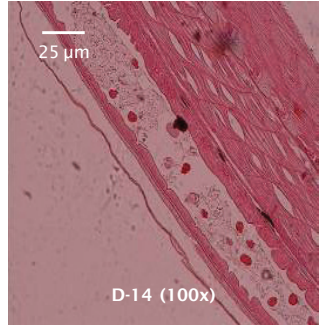

Bioflok + pengurangan rotifer 25\% (Biofloc + reduction of rotifer $25 \%$

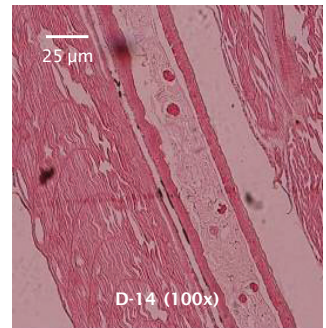

Bioflok + pengurangan rotifer $50 \%$ (Biofloc + re duction of rotifer $50 \%$

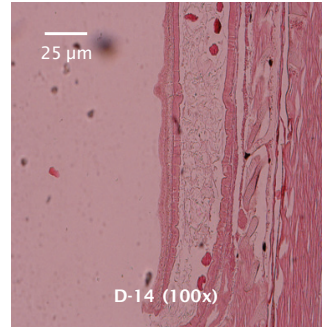

Kontrol tanpa bioflok Control without biofloc

Gambar 6. Struktur histologi usus pada benih ikan bandeng (D-14) dengan perlakuan aplikasi bioflok dan tanpa bioflok

Figure 6. Histological structure in intestine of milkfish fry (D-14) treated with and without biofloc application

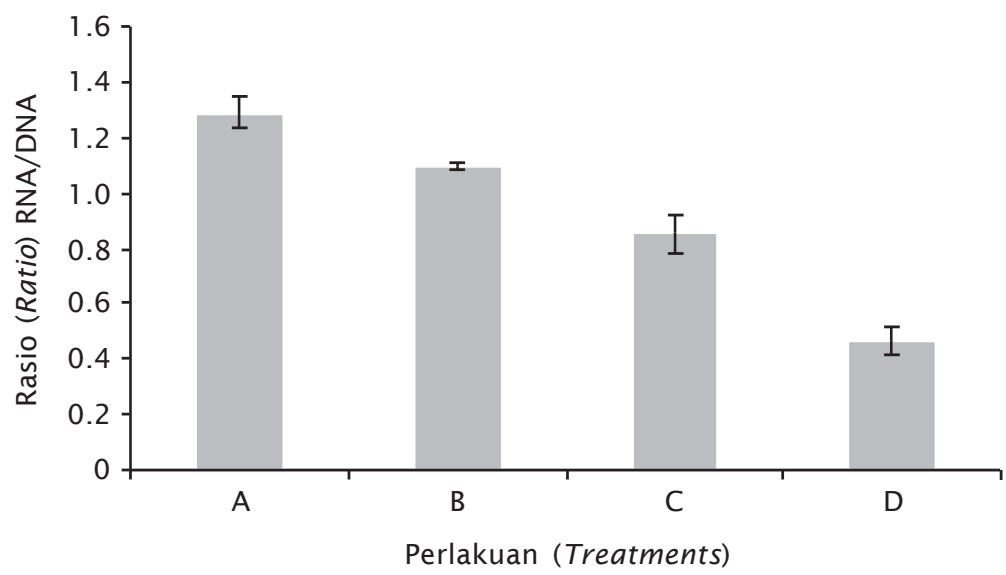

Gambar 7. Nilai rasio RNA/DNA benih ikan bandeng, (A) bioflok+ rotifer $100 \%$, (B) bioflok + pengurangan rotifer $25 \%$, (C) bioflok + pengurangan rotifer $50 \%$, (D) kontrol tanpa bioflok

Figure 7. RNA/DNA ratio of milkfish fry, (A) biofloc + rotifer $100 \%,(B)$ biofloc + reduction 25\% rotifer, (C) biofloc + reduction 50\% rotifer, (D) control without biofloc

untuk mendiagnosis kondisi nutrisi (nutritional condition) pada ikan Japanese anchovy (Engraulis japonicus). Dengan demikian konsentrasi rasio RNA/DNA akan berpengaruh terhadap sifat-sifat kualitatif maupun kuantitatif benih yang dihasilkan. Informasi yang diperoleh tersebut dapat dijadikan indikasi sifat fisiologi, genetik, dan keragaan morfologi. Banyak penelitian yang mengemukakan bahwa variasi pertumbuhan larva ikan Atlantic cod dipengaruhi oleh kualitas air, pakan dan rasio RNA/DNA sekitar 92\% (Caldarone \& Buckley, 1997).

\section{Uji Vitalitas}

Uji vitalitas benih ikan bandeng dengan menggunakan formalin dan pengeringan terlihat pada Tabel 2. Kualitas benih ikan bandeng dengan uji kimia dan fisik menunjukkan hasil yang berbeda secara signifikan $(P<0,05)$. Dengan pemberian aplikasi bioflok pada pemberian formalin sampai $300 \mathrm{mg} / \mathrm{L}$ mampu bertahan hidup dengan sintasan berkisar antara 24,04\%-31,64\%. Hal ini sangat berbeda jika dibandingkan dengan kontrol (0\%). Pada uji fisik dengan pengeringan benih hanya mam- 


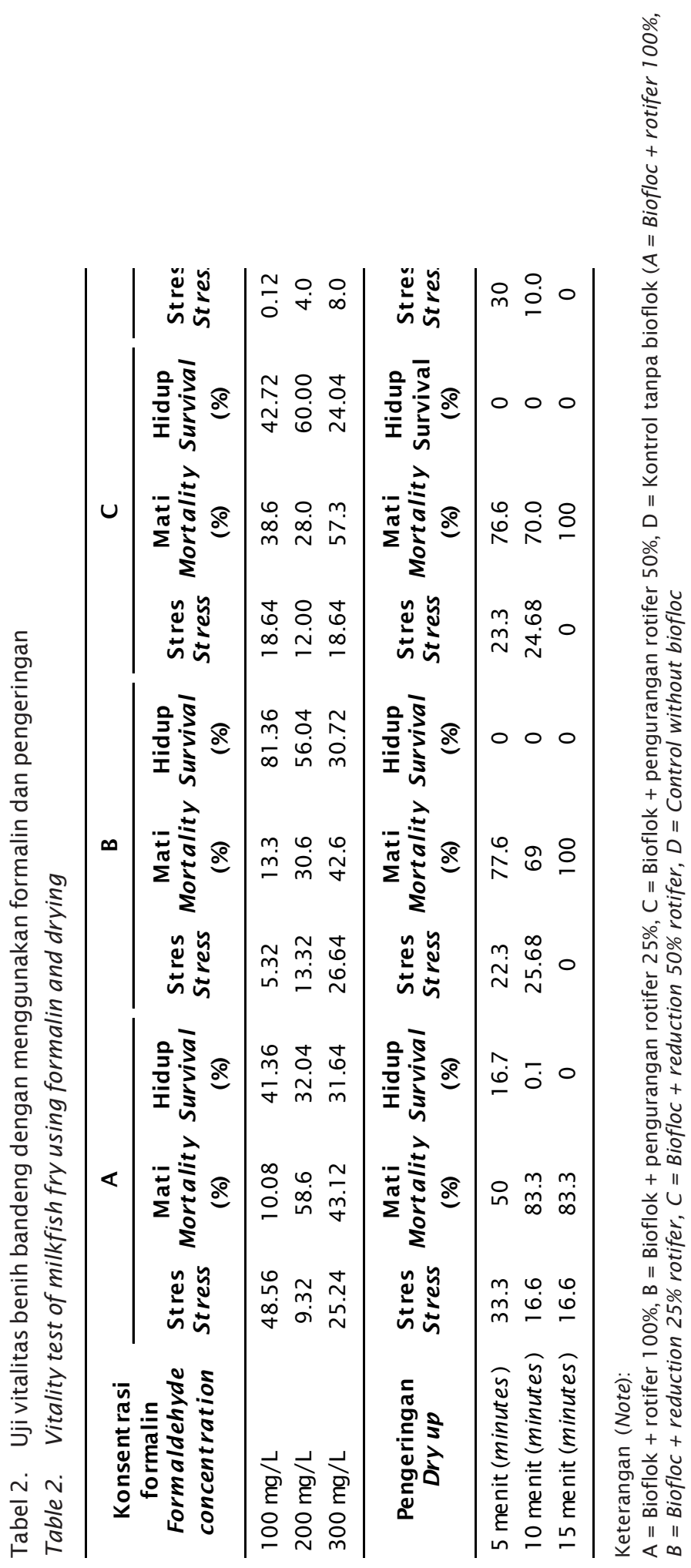


pu bertahan dengan pengeringan lima menit pada perlakuan bioflok + rotifer $100 \%$ adalah 16,7\%; sedangkan perlakuan lainnya dan kontrol tidak ada yang hidup.

Populasi Total Bakteri dan Vibrio pada Media Pemeliharaan Ikan Bandeng

Bila dilihat dari populasi total bakteri dan Vibrio (Tabel 3), menunjukkan jumlah yang fluktuatif sepanjang penelitian. Jumlah total bakteri tertinggi pada semua perlakuan terjadi pada hari ke delapan hingga ke-16 (25$875 \times 10^{2} \mathrm{cfu} / \mathrm{mL}$ ). Sementara, populasi Vibrio pada semua perlakuan relatif stabil $(<20 x$ $10^{2} \mathrm{cfu} / \mathrm{mL}$ ), dengan koloni Vibrio berwarna kuning, walaupun pada hari akhir penelitian populasi Vibrio meningkat. Koloni warna hijau yang lebih patogen terlihat pada kontrol dan perlakuan bioflok + pengurangan rotifer 50\%. Dari hal tersebut dapat diduga bahwa dengan terbentuknya bioflok dapat berperan sebagai agen anti mikrobial terutama Vibrio patogen.

\section{Kualitas Air Pemeliharaan Ikan Bandeng}

Hasil pemantauan kualitas air (suhu, pH, dan amonia) dalam media pemeliharaan ikan bandeng dengan mengaplikasikan bakteri pembentuk bioflok yang berbeda disajikan pada Tabel 4. Terlihat bahwa kandungan amonia media pemeliharaan pada semua perlakuan tidak berbeda nyata. Tingginya konsentrasi amonia $\left(\mathrm{NH}_{3}\right)$ pada kontrol diduga kandungan rasio $\mathrm{C} / \mathrm{N}$ yang rendah, sehingga mikroba akan menggunakan nitrogen organik (asam amino, urea, protein) dan melepas amonia. Bila rasio $\mathrm{C} / \mathrm{N}$ tinggi maka mikroba akan menggunakan nitrogen anorganik (amonia, nitrat, nitrit) untuk disintesis menjadi protein. Lebih lanjut menurut Sinka (2008), menyatakan bahwa peran bioflok adalah memperbaiki kualitas air pemeliharaan udang.

Pada Tabel 4, terlihat bahwa suhu dan $\mathrm{pH}$ menunjukkan nilai yang relatif stabil pada semua perlakuan. Nilai amonia $\left(\mathrm{NH}_{3}\right)$ pada kontrol terlihat lebih tinggi sebagai akibat dari tidak berfungsinya mikroba dan bahan organik sehingga terjadi penumpukan $\mathrm{N}$ yang berasal dari pakan.

\section{KESIMPULAN}

Penerapan teknologi bioflok pada pemeliharan larva bandeng di hatcheri dapat meningkatkan kualitas dan kuantitas benih.

\section{UCAPAN TERIMA KASIH}

Ucapan terima kasih sebesar-besarnya disampaikan kepada rekan-rekan teknisi litka-

Tabel 3. Kepadatan bakteri flok pada bak penelitian ikan bandeng

Table 3. Density of bacteria floc in the rearing tank of milkfish hatchery

\begin{tabular}{ccccc}
\hline $\begin{array}{c}\text { Perlakuan } \\
\text { Treatments }\end{array}$ & $\begin{array}{c}\text { Total bakteri } \\
\text { Total of bacteria } \\
(\mathrm{cfu} / \mathrm{mL})\end{array}$ & $\begin{array}{c}\text { Warna koloni } \\
\text { Colony colour }\end{array}$ & $\begin{array}{c}\text { Jumlah Vibrio } \\
\text { Number of Vibrio } \\
\text { (cfu/mL) }\end{array}$ & $\begin{array}{c}\text { Warna koloni } \\
\text { Colony colour }\end{array}$ \\
\hline A & $80 \times 10^{2}$ & $\begin{array}{c}\text { Koloni putih } \\
\text { White colonies } \\
\text { Koloni putih } \\
\text { White colonies } \\
\text { Koloni putih } \\
\text { Bhite colonies } \\
\text { (Foaming) } \\
\text { Koloni putih }\end{array}$ & 180 & Kuning (Yellow) \\
C & $25 \times 10^{2}$ & 100 & Kuning (Yellow) \\
White colonies & $135 \times 10^{2}$ & 170 & $\begin{array}{c}\text { Kuning (Yellow) } \\
\text { Hijau (Green })^{*}\end{array}$ \\
\hline
\end{tabular}

Keterangan (Note):

- $A=$ Bioflok + rotifer $100 \%, B=$ Bioflok + pengurangan rotifer $25 \%, C=$ Bioflok + pengurangan rotifer $50 \%$,

$\mathrm{D}=$ Kontrol tanpa bioflok $(A=$ Biofloc + rotifer $100 \%, B=$ Biofloc + reduction $25 \%$ rotifer,$C=$ Biofloc + reduction $50 \%$ rotifer, $D=$ Control without biofloc

- "Koloni hijau lebih patogen (Green colony more pathogen) 
Tabel 4. Kisaran kualitas air dalam pemeliharaan ikan bandeng dengan pemberian bakteri pembentuk bioflok

Table 4. Ranged of water quality values in rearing water tank of milkfish after treated with bacteria forming biofloc

\begin{tabular}{lcccc}
\hline $\begin{array}{c}\text { Parameter } \\
\text { Parameters }\end{array}$ & $\begin{array}{c}\text { A } \\
(\boldsymbol{m} \text { in.-max. })\end{array}$ & $\begin{array}{c}\text { B } \\
(\boldsymbol{m} \text { in.-max. })\end{array}$ & $\begin{array}{c}\text { C } \\
(\boldsymbol{m} \text { in.-max. })\end{array}$ & $\begin{array}{c}\text { D } \\
(\boldsymbol{m} \text { in.-max. })\end{array}$ \\
\hline Suhu (Temperature) $\left({ }^{\circ} \mathrm{C}\right)$ & $28.5-29.1$ & $28.3-29.0$ & $28.3-29.2$ & $28.3-29.0$ \\
$\mathrm{pH}$ & $7.31-8.25$ & $7.90-8.36$ & $7.74-8.5$ & $8.29-8.40$ \\
$\mathrm{NH}_{3}(\mathrm{mg} / \mathrm{L})$ & $0.039-0.314$ & $0.037-0.552$ & $0.046-0.373$ & $0.074-1.042$ \\
\hline
\end{tabular}

Keterangan (Note):

Bioflok $+100 \%$ rotifer (A), bioflok + (-) $25 \%$ rotifer (B), bioflok + (-) $50 \%$ rotifer (C), kontrol tanpa bioflok (D) Biofloc with standar feeding $100 \%$ rotifer (A), biofloc with reduction of feeding rate $25 \%$ (B), biofloc with reduction of feeding rate $50 \%$ (C), without added biofloc as control (D)

yasa kelompok Bioteknologi dan ikan tuna BBPPBL Gondol atas kerja sama dan bantuannya dengan penuh tanggung jawab sehingga riset ini dapat terlaksana dengan baik. Penelitian ini dibiayai dari APBN Kementerian Kelautan dan Perikanan Tahun Anggaran 2010.

\section{DAFTAR ACUAN}

Anonymous. (2008). Concept of heterotrophic bacteria system using bioflocs in shrimp aquaculture. Shirotabiota Indonesia, p. 114.

Avnimelech, Y. (2007). Feeding with microbial flocs by tilapia in minimal discharge bioflocs technology ponds. Aquaculture, 264, 140-147.

Azim, M.E. \& Little, D.C. (2008). The biofloc technology (BFT) indoor tanks: Water quality, biofloc composition, and growth and walfare of nile tilapia (Oreochromis niloticus). Aquaculture, 283(1-4), 29-35.

Briggs, M. (2007). Biofloc prawns culture systems. www.dpi.qld.gov.au/cps/rde/xchg/ dpi/ hs. xsl/30_7271_ENA_HTML.htm. diakses tanggal 8 April 2008.

Buckley, L.J. (1984). RNA-DNA ratios: an index of larval fish growth in the sea. Mar. Biol., 80, 291-298.

Caldarone, E.M. \& Buckley, L.J. (1997). Relationship between RNA/DNA ratio, temperature and growth rate in Atlantic cod larvae. Ichthyoplankton Ecology Fisheries Society of the British Isles., $50 \mathrm{pp}$.

Chicharo, M.A., Chicharo, L., Valdes, L., LopezJarnar, E., \& Re, P. (1998). Estimation of starvation and diet variation the RNA/DNA rasios in field-caught Sardina pilcardus lar- vae of the north of Spain. Mar. Ecol., 164, 273-283.

Conquest, L. \& Tacon, A.G.J. (2006). Utilization of microbial floc in aquaculture systems: a review. Aquaculture America Annual Meeting. Las Vegas, NV, 13-16 February 2006, 9 pp.

Ebeling, J.M., Timmons, M.B., \& Bisogni, J.J. (2006). Engineering analysis of the stoichiometry of photoautrophic, autotrophic and heterotrophic removal of ammonia-nitrogen in aquaculture system. Aquaculture, 257, 346-358.

Haryanti, Mahardika, K., Permana, G.N., \& Moria, S.B. (2006). Study on fry performance of black tiger shrimp, Penaeus monodon with special reference to its morphology and RNA/DNA ratio analysis. Indonesian Aquaculture Journal, 1(2), 159-164.

Jung, T. \& Clemmesen, C. (1997). Effect of different food organism on the development and nutritional condition of cod larvae ( $\mathrm{Ga}$ dus morhua L.) in laboratory rearing experiment. Ichthyoplankton Ecology Fisheries Society of the British Isles, $50 \mathrm{pp}$.

Kono, N., Tsukamoto, Y., \& Zenitani, H. (2003). RNA:DNA ratio for diagnosis of the nutritional condition of Japanese anchovy, Egraulis japonicus larvae during the first feeding stage. Fisheries Science, 69, 10961102.

McIntosh, P.R. (2000). Changing paradigma in shrimp farming: IV Low protein feeds and feeding strategies. Global Aquaculture Advocate, 3, 44-50.

Ovenden, J. (2000). Development of restriction enzyme marker of red snapper (Lutjanus 
erythropterus and Lutjanus malabaricus) stock discrimination using genetic variation in mitochondria DNA. Molecular Fisheries Laboratory, Southtern Fisheries Centre.

Sinka, A.K. (2008). New Caledonia Breaks: Shrimp Inbreeding Aquaculture Health International, Issue 13, June 2008.

Segnini, M.I. \& Chung, K.S. (1997). Influence of environmental factors on the instant growth of tropical fishes assessed by the RNA/DNA relationship. Biol. Inst. Oceanogr. Venez., 36(1/2), 21-29.

Wilson, G. (2008). Biofloc Aquaculture - 30 times more productive than ponds. Growfish. Gippsland Aquaculture Industri Network Inc. www.growfish.com.au/ content. asp?contentid=7196. diakses tanggal 8 April 2008. 